\title{
A Novel Hybrid Axial-Radial Atmospheric Plasma Spraying Technique for the Fabrication of Solid Oxide Fuel Cell Anodes Containing $\mathrm{Cu}, \mathrm{Co}, \mathrm{Ni}$, and Samaria-Doped Ceria
}

\author{
Mark Cuglietta, Joel Kuhn, and Olivera Kesler
}

\author{
(Submitted September 30, 2012; in revised form January 22, 2013)
}

\begin{abstract}
Composite coatings containing $\mathrm{Cu}, \mathrm{Co}, \mathrm{Ni}$, and samaria-doped ceria (SDC) have been fabricated using a novel hybrid atmospheric plasma spraying technique, in which a multi-component aqueous suspension of $\mathrm{CuO}, \mathrm{Co}_{3} \mathrm{O}_{4}$, and $\mathrm{NiO}$ was injected axially simultaneously with SDC injected radially in a dry powder form. Coatings were characterized for their microstructure, permeability, porosity, and composition over a range of plasma spray conditions. Deposition efficiency of the metal oxides and SDC was also estimated. Depending on the conditions, coatings displayed either layering or high levels of mixing between the SDC and metal phases. The deposition efficiencies of both feedstock types were strongly dependent on the nozzle diameter. Plasma-sprayed metal-supported solid oxide fuel cells utilizing anodes fabricated with this technique demonstrated power densities at $0.7 \mathrm{~V}$ as high as 366 and $113 \mathrm{~mW} / \mathrm{cm}^{2}$ in humidified hydrogen and methane, respectively, at $800^{\circ} \mathrm{C}$.
\end{abstract}

Keywords anode, cobalt, copper, nickel, plasma spray, samaria-doped ceria (SDC), solid oxide fuel cell (SOFC)

\section{Introduction}

The solid oxide fuel cell (SOFC) is a solid-state electrochemical device capable of converting the chemical energy in hydrogen and hydrocarbon fuels directly into electricity and heat with high efficiency. One significant advantage of directly oxidizing a hydrocarbon fuel inside an SOFC is that the process of reforming the hydrocarbon to hydrogen is eliminated, which improves the efficiency of fuel conversion and lowers the balance of plant costs for any reforming or steam generation steps performed externally to the fuel cell stack. Some of the disadvantages to operating an SOFC directly on hydrocarbon fuels are reduced electrochemical performance and cell degradation or damage due to solid carbon formation or coking (Ref 1). Conventional SOFC anodes are cermets containing both nickel and yttria-stabilized zirconia (YSZ). In addition to having a relatively low cost compared to the precious metal

Mark Cuglietta, Joel Kuhn, and Olivera Kesler, Mechanical and Industrial Engineering Department, University of Toronto, 5 'King's College Road, Toronto, ON M5S 3G8, Canada. Contact e-mails:mark.cuglietta@utoronto.ca,joel.kuhn@utoronto.ca, and kesler@mie.utoronto.ca. catalysts commonly used in other fuel cell technologies, nickel has proven to be an excellent catalyst for the electrochemical oxidation of both hydrogen and hydrocarbon fuels in SOFCs. Nickel is also an excellent catalyst for hydrocarbon cracking and the subsequent coking at SOFC operating temperatures, making it not suitable alone as the metal component of a direct oxidation SOFC ( Ref 2).

Numerous works have been conducted on various systems designed to replace the conventional Ni-YSZ system in direct oxidation SOFC anodes. In the conventional system, nickel acts as both a catalyst and an electronic conductor and must be present in amounts greater than approximately $30 \mathrm{vol} \%$ in order to surpass the percolation threshold and be suitably conductive (Ref 3 ). One alternative design is based on the concept of decoupling the catalyst phase in the anode from the electronically conductive phase. This way, smaller amounts of the catalyst can be used, which leads to a reduction in surface area for solid carbon formation. When small amounts of very active catalysts with high surface area are included inside a highly conductive ceramic or metal scaffold, the amount of coking is reduced to a level that is sustainable for longterm cell operation without significantly affecting performance. Liu et al. demonstrated this concept for an anode utilizing the perovskite $\mathrm{La}_{0.8} \mathrm{Sr}_{0.2} \mathrm{Cr}_{0.8} \mathrm{Mn}_{0.2} \mathrm{O}_{3-\delta}$ (LSCM) and fluorite $\mathrm{Ce}_{0.9} \mathrm{Gd}_{0.1} \mathrm{O}_{1.95}$ (GDC) as electronic and ionic conductors, respectively, and only $4 \mathrm{wt} \% \mathrm{Ni}$ as a catalyst (Ref 4). For the anode containing $4 \mathrm{wt} . \% \mathrm{Ni}$, a power density of only $5 \%$ less than that of an anode containing 50 wt.\% Ni combined with GDC was reported for operation in humidified propane at $750{ }^{\circ} \mathrm{C}$. In addition, the 
authors reported a significant reduction in solid carbon formation. Similarly, Lee et al. were able to operate an SOFC stably in humidified methane at $800{ }^{\circ} \mathrm{C}$ for $500 \mathrm{~h}$ using an anode containing only $15 \mathrm{wt} \% \mathrm{Co}$ as the catalyst phase (Ref 5).

In addition to optimizing the amount of catalyst in the anode, selecting material for the electronic and ionic conducting phases that are highly conductive and not catalytic toward coking is necessary for maximum performance and minimal carbon formation. Coking is less of a problem for the ionic conducting phase because carbon species do not easily dissolve in oxides (Ref 6), a step considered necessary for destructive long-chain carbon growth (Ref 7). $\mathrm{Sm}_{0.2} \mathrm{Ce}_{0.8} \mathrm{O}_{1.9}$ (SDC) is considered an excellent candidate as a component of a direct oxidation anode because it is a mixed ionic and electronic conductor in reducing atmospheres with a conductivity over 3 times higher than that of YSZ at SOFC operating temperatures (Ref 8). Also, ceria has been demonstrated to be a mild catalyst for both hydrogen and hydrocarbon oxidation (Ref 9). Choosing an electronic conducting phase with high conductivity and little tendency to catalyze coking is more difficult since many commonly used metals have catalytic properties toward hydrocarbon oxidation (Ref 10) and the attendant carbon formation reactions (Ref 11). One metal that has excellent conductivity and has been shown to have little propensity toward carbon growth is copper. The group at the University of Pennsylvania pioneered the use of copper as part of a direct oxidation SOFC and has reported multiple studies on the performance and stability of copper-based anodes operated with hydrocarbon fuels (Ref $2,5,12-14)$. In addition to demonstrating that another more active catalyst is required to improve performances in hydrocarbon fuels, they also showed that stabilization of the copper phase is probably necessary for long-term cell operation at higher temperatures $\left(\geq 800^{\circ} \mathrm{C}\right)$ due to copper's relatively low melting temperature $\left(1084^{\circ} \mathrm{C}\right)$. Specifically, cobalt was demonstrated to be an effective additive for thermally stabilizing copper, a result which was attributed to the immiscibility of cobalt in copper (Ref 15), along with the tendency for copper to migrate to the surface of cobalt (Ref 14). Since cobalt was also shown to be an effective catalyst for methane oxidation, its quantity in the electrode must also be limited to less than $18 \mathrm{wt} . \%$ in order to mitigate unsustainable carbon growth (Ref 5).

Owing to its potential to drastically decrease the time required to fabricate an SOFC on a metal support structure, thermal plasma spraying is viewed as a promising alternative for manufacturing cells at reduced costs (Ref 16). While many studies have been devoted to the development of plasma spray processes for fabricating anode layers containing Ni and YSZ, less work has been conducted on developing processes for plasma spraying layers containing $\mathrm{Cu}$ or Co. Benoved and Kesler (Ref 17) demonstrated the use of the atmospheric plasma spray process for fabricating SOFC anodes based on $\mathrm{Cu}$ and SDC using a three-cathode plasma spray torch. As a result of the difference in melting temperature between $\mathrm{CuO}\left(1227^{\circ} \mathrm{C}\right)$ and $\operatorname{SDC}\left(\sim 2600{ }^{\circ} \mathrm{C}\right)$, they found that the relative deposition efficiency of the
$\mathrm{CuO}$ to the SDC varied widely from 3 to 0.75 over plasma powers ranging from 40 to $80 \mathrm{~kW}$. The higher plasma powers required to melt the SDC led to vaporization of the $\mathrm{CuO}$ in flight and highly melted $\mathrm{CuO}$ in the resultant coatings. Benyoucef et al. (Ref 18) published a study on the development and characterization of cermet layers containing $\mathrm{Cu}, \mathrm{Co}, \mathrm{Ni}$, and YSZ. They found that the porosity of the layers trended inversely with metal content, presumably because of dense metal regions in the coatings as a result of high levels of melting relative to the YSZ during processing. In both studies, the level of mixing between the metals and the SDC or YSZ was limited by the sizes of the powders used for processing. Suspension plasma spraying has been recognized as an effective way to reduce the sizes of features and increase the levels of mixing in plasmasprayed coatings because more finely sized, higher surface area powders can be used in the feedstock (Ref 19, 20). Layers with a finer structure that function well as the electrode of an SOFC have a higher concentration of triplephase boundary sites, which serve as the locations of the electrochemical reactions in the anode.

The purpose of this study was to evaluate the suspension plasma spray process for fabricating SOFC anode layers containing mainly copper and SDC and relatively smaller amounts of cobalt and nickel. To date, no studies have been reported on the fabrication of SOFC anode layers based on copper using a suspension plasma spray process. Because of the challenges associated with co-spraying metals or binary metal oxides with a more refractory ceramic such as SDC, specifically the wide range of relative deposition efficiencies of the phases and the high levels of melting of the binary oxide feedstocks during processing, a single suspension containing all of the constituents of the anode layer was bypassed in favor of a novel plasma spray process utilizing a combination of conventional and suspension plasma spray methods. A hybrid process, which involved the plasma spraying of an aqueous suspension of metal oxides based on $\mathrm{Cu}, \mathrm{Co}$, and $\mathrm{Ni}$ simultaneously with SDC in dry powder form was chosen for three reasons. First, because of the extra energy and time required to evaporate the aqueous medium of the suspension before melting the solid particles, the effect of the large gap in melting temperatures between the metal oxides and the SDC may be reduced, leading to more equal rates of melting of the two types of feedstock and elimination of the necessity for excess metal oxides in the feedstock. Second, larger SDC particle sizes in the dry powder may be used to promote partial melting of the SDC, resulting in a more disordered buildup of splats in the coating and higher levels of porosity. Third, metal oxide powders with finer particle sizes can be used to reduce the sizes of the metal structures in the coatings and increase the concentration of the triple-phase boundary sites.

Coatings fabricated in this study using a range of plasma spray conditions were characterized by their porosity, permeability, composition, and microstructure. Also, the deposition efficiency of each feedstock was estimated. The metal oxides chosen as components of the suspension were $\mathrm{CuO}, \mathrm{Co}_{3} \mathrm{O}_{4}$, and $\mathrm{NiO}$. The concentrations of $\mathrm{Co}_{3} \mathrm{O}_{4}$ and $\mathrm{NiO}$ in suspension were chosen so that the concentrations 
Table 1 Particle size distribution and preparation details of the individual components and fully prepared aqueous multi-component suspension used for plasma spraying

\begin{tabular}{|c|c|c|c|c|c|}
\hline & Concentration ${ }^{\mathrm{a}}$, wt. $\% /$ solids & Dispersant & $d_{10}, \mu \mathrm{m}^{\mathrm{b}}$ & $d_{50}, \mu \mathrm{m}$ & $d_{90}, \mu \mathrm{m}$ \\
\hline $\mathrm{CuO}$ & 58.3 & PBTCA $^{c}$ & 1.9 & 5.4 & 81 \\
\hline $\mathrm{Co}_{3} \mathrm{O}_{4}$ & 33.8 & None & 2.0 & 9.9 & 25 \\
\hline $\mathrm{NiO}$ & 7.9 & None & 0.39 & 1.2 & 9.5 \\
\hline Suspension & - & - & 1.1 & 2.5 & 5.8 \\
\hline \multicolumn{6}{|c|}{$\begin{array}{l}\text { a } \text { Based on bulk densities of } \mathrm{CuO}, \mathrm{Co}_{3} \mathrm{O}_{4} \text {, and } \mathrm{NiO} \text { of } 6.31,6.11 \text {, and } 6.72 \mathrm{~g} / \mathrm{cm}^{3} \text {, respective } \\
5 \text { vol. } \% \\
\text { b } \text { By volume } \\
\text { c } 2 \text {-Phosphonobutane-1,2,4-tricarboxylic acid (Dequest } 7000^{\circledR} \text {, Thermphos, Switzerland) }\end{array}$} \\
\hline
\end{tabular}

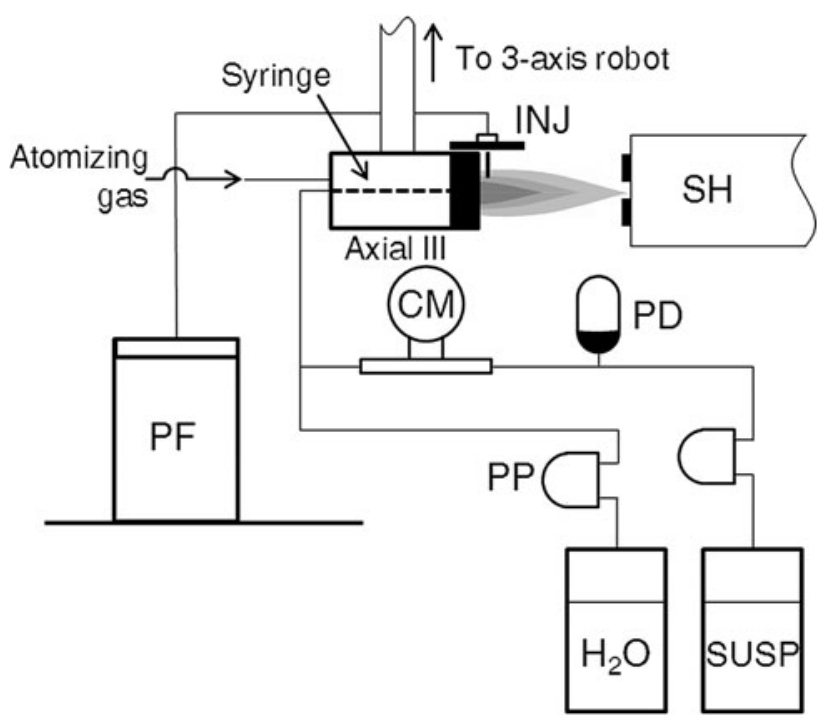

Fig. 1 Schematic showing the setup used for plasma spraying composite coatings using both radial and axial feedstock injection ( $\mathrm{PF}$ - powder feeder; $\mathrm{PP}$ - peristaltic pump; $\mathrm{CM}$ - coriolis meter; $\mathrm{PD}$ - pulse dampener; $\mathrm{SH}$-substrate heater; INJ-radial injector)

of $\mathrm{Co}$ and $\mathrm{Ni}$ metals in the coatings were limited to 16 and 4 wt. \%, respectively, in order to provide more stability of the anodes in hydrocarbon fuels. Metal-supported SOFCs utilizing these coatings as anodes and fabricated entirely by atmospheric plasma spraying were assessed for their performance in both hydrogen and methane.

\section{Experimental Procedure}

\subsection{Materials}

The fine cut of a spray-dried SDC powder $\left(\mathrm{Sm}_{0.2} \mathrm{Ce}_{0.8} \mathrm{O}_{1.9}\right.$, Inframat Advanced Materials, Manchester, CT, USA) was used as the radially injected feedstock for plasma spraying. Measurement of the particle size distribution of this powder using a laser light scattering technique (Mastersizer 2000, Malvern Instruments Ltd., Worcestershire, UK) yielded $d_{10}, d_{50}$, and $d_{90}$ sizes (by volume) of 2.0, 6.7, and $17.0 \mu \mathrm{m}$, respectively. Measure- ment of the particle size after delivery through the vibratory dry powder feeder (Thermico CPF, Thermico $\mathrm{GmbH} \&$ Co., Dortmund, DE) revealed no significant change in the particle size, suggesting that breakup of the spray-dried agglomerates during powder feeding did not occur. The SDC powder was stored in a drying oven at $175^{\circ} \mathrm{C}$ for at least $24 \mathrm{~h}$ prior to fabricating coatings in order to minimize flow disturbances from clogging during spraying. In some cases, graphite $\left(d_{50}\right.$ by volume $\left.\sim 22 \mu \mathrm{m}\right)$ (OMAC2, Osaka Gas Chemicals Co., Osaka, JP) or common potato starch (Bulk Barn, Toronto, CAN) sieved to a size fraction of $-45+32 \mu \mathrm{m}$ was added as pore former to the SDC powder at a concentration of $25 \mathrm{wt} . \%$ relative to SDC in order to further improve the resultant open porosity to levels suitable for an SOFC electrode.

A multi-component aqueous suspension of $\mathrm{CuO}$, $\mathrm{Co}_{3} \mathrm{O}_{4}$ ("Nanopowder," Inframat, Manchester, CT), and $\mathrm{NiO}$ ("Fine," Novamet, Wyckoff, NJ) at a total concentration of $5 \mathrm{vol} \%$ was used for delivery of the binary metal oxides to the plasma spray torch. Particle sizes of the constituent powders, along with suspension preparation details, are provided in Table 1. Details of the development of this suspension can be found in another study (Ref 21). The concentration of each individual metal oxide in suspension targets relative concentrations in the metal phases of the coatings of 8,32 , and 60 wt. \% Ni, Co, and $\mathrm{Cu}$, respectively, after reduction.

\subsection{Plasma Spraying}

Plasma spraying was carried out using a three-cathode torch with an axially aligned feed tube (Axial III, Northwest Mettech Corp., North Vancouver, Canada). The simultaneous radial injection of the SDC phase was accomplished using a custom mounting block fastened to the body of the torch that allowed for positioning of the injection location in both the axial and radial directions. A schematic of the setup used for fabricating coatings with this technique is provided in Fig. 1. A stainless steel syringe inserted into the axial feed tube allowed for delivery of the suspension to the plasma. Laser-welded ribs at the end of the syringe kept the syringe positioned in the center of the torch's feed tube and prevented oscillations at the injection point due to the flow of the argon atomizing gas in the surrounding tube annulus. Suspension and water flow were controlled using two separate peristaltic pumps. 
Table 2 Processing parameters investigated for fabricating composite SOFC anode coatings containing $\mathrm{Cu}, \mathrm{Co}$, Ni, and SDC

\begin{tabular}{|c|c|c|}
\hline \multicolumn{2}{|l|}{ Parameter } & Range \\
\hline \multicolumn{2}{|c|}{ Arc Current per Cathode (A) [Total Current (A)] } & $150-250[450-750]$ \\
\hline \multicolumn{2}{|c|}{ Plasma Gas Flow Rate (SLPM) } & $150-250$ \\
\hline \multicolumn{2}{|c|}{ Nozzle Diameter (mm [in.]) } & $7.9[0.3125], 9.5[0.375], 11.1[0.4375]^{\mathrm{a}}, 12.7[0.5]$ \\
\hline \multirow{3}{*}{$\begin{array}{l}\text { Plasma } \\
\text { Gas } \\
\text { Composition }\end{array}$} & $\operatorname{Ar}(\%)$ & $10-70,55^{\mathrm{a}}$ \\
\hline & $\mathrm{N}_{2}(\%)$ & $20-80,40^{\mathrm{a}}$ \\
\hline & $\mathrm{H}_{2}(\%)$ & $0-10,5^{\mathrm{a}}$ \\
\hline \multicolumn{2}{|c|}{ Standoff Distance (mm) } & $50^{\mathrm{a}}, 100$ \\
\hline \multicolumn{2}{|c|}{ SDC Carrier Gas $\left(\mathrm{N}_{2}\right)$ Flow Rate (SLPM) } & $10-15$ \\
\hline \multicolumn{2}{|c|}{ Atomizing Gas (Ar) Flow Rate (SLPM) } & $5-20$ \\
\hline \multicolumn{2}{|c|}{ Suspension Syringe Diameter (mm) } & 0.838 \\
\hline \multicolumn{2}{|c|}{ Suspension Concentration (vol. \%) } & 5 \\
\hline \multicolumn{2}{|c|}{ Total Solid Feed Rate (g/min) } & $19.0 \pm 1.0$ \\
\hline \multicolumn{2}{|c|}{ Substrate Pre-Heat Temperature $\left({ }^{\circ} \mathrm{C}\right)$} & 300 \\
\hline \multirow{2}{*}{$\begin{array}{l}\text { Radial Injector } \\
\text { Position }\end{array}$} & Axial Distance (mm) & 8 \\
\hline & Radial Distance (mm) & 13 \\
\hline
\end{tabular}

a "Nominal" condition

Water was used solely for flushing the syringe after each spray run to prevent the formation of deposits and clogging. A pulse dampener provided for a more steady suspension flow rate, while a coriolis meter measured the suspension feed rate. The feed rate of the SDC powder was measured by calibrating the dry powder feeder prior to spraying. The torch was controlled using a 3-axis robot. Coatings were fabricated using a torch raster pattern with a step size of approximately $4 \mathrm{~mm}$ and a peak torch speed of approximately $60 \mathrm{~cm} / \mathrm{s}$ at the substrates.

Substrates were preheated using a custom temperature control and mounting system and were kept cool during spraying through the use of rear-mounted spring-loaded thermocouples that controlled the flow of a cool air stream. The substrates were either dense or porous 430 stainless disks $25.4 \mathrm{~mm}$ in diameter and $1.6 \mathrm{~mm}$ in thickness. The porous disks are primarily designed for filtering applications and contain porosities fit for filtering media larger than either $0.2 \mu \mathrm{m}$ (MG0.2) or $1 \mu \mathrm{m}$ (MG1) (Mott Corporation, Farmington, CT, USA) in size.

In order to determine the plasma spray conditions suitable for fabricating composite anode coatings with suitable composition, good adhesion, and good porosity with reasonable deposition efficiency, a range of process parameters was studied and is provided in Table 2. The plasma spray conditions that most consistently led to all of these properties are labeled as the "nominal" condition. The target solid mass feed ratio between the metal oxides in suspension and the SDC was chosen to be 1.29:1, which corresponds to a composition of $44 \mathrm{vol} \%$ metal and 56 vol.\% SDC (50/50 wt.\%) after reduction.

\subsection{Coating Characterization}

Deposition efficiency (DE) of the coatings was determined by weighing the substrates before and after spraying. The DE was estimated using the measured mass feed rate of each of the two feedstocks, the torch speed, and an average of the minimum and maximum length of the path of the torch over the substrate, based on the raster step size. X-ray diffraction (XRD) of the coatings prior to and after reduction was conducted using $\mathrm{Cu}-\mathrm{K}_{\alpha}$ radiation at an acceleration voltage of $40 \mathrm{kV}$ (Philips PW 1830 HT generator and PW 1050 goniometer, Almelo, The Netherlands). The coatings and substrates were mounted in epoxy and sectioned with a diamond wafering blade and subsequently polished following standard metallographic preparation procedures. Coating cross sections and the SDC powder were imaged under a scanning electron microscope (SEM) (JEOL JSM6610, Tokyo, Japan) equipped with an energy dispersive spectrometer (EDS) (INCAx-act, Oxford Instruments, Oxfordshire, UK). Coating composition was measured using an average of three EDS scans over three separate areas of the coating $200-400 \mu \mathrm{m}$ wide. Since the composition of interest was that of a working anode in which the $\mathrm{CuO}, \mathrm{Co}_{3} \mathrm{O}_{4}$, and $\mathrm{NiO}$ are reduced to their metallic state, the composition was determined using the ratios of the metal cations only. To determine the relative amount of SDC in the coatings, the bulk powder stoichiometry $\left(\mathrm{Sm}_{0.2} \mathrm{Ce}_{0.8} \mathrm{O}_{1.9}\right)$ was used along with the measured $\mathrm{Ce}$ concentration.

The permeability of the coatings after reduction in hydrogen was determined using a custom device that sealed 
the substrate and coating on both sides and allowed controlled pressurization of one side with air and the measurement of the resultant air flow rate on the other. The coatings were first reduced in $40 \% \mathrm{H}_{2}$ (balance $\mathrm{N}_{2}$ ) at a temperature of $600{ }^{\circ} \mathrm{C}$ for $2 \mathrm{~h}$. For coatings fabricated with graphite pore former, the graphite was burned out in air at $700{ }^{\circ} \mathrm{C}$ for $2 \mathrm{~h}$ prior to reduction. The permeability coefficient, $k$, was calculated using Darcy's Law, defined in Eq 1.

$k=\frac{Q \mu L}{A\left(P_{1}-P_{2}\right)}\left(\mathrm{m}^{2}\right)$

In this case, $Q$ is the measured gas flow rate $\left(\mathrm{m}^{3} / \mathrm{s}\right), \mu$ is the viscosity of air $(\mathrm{Pa} / \mathrm{s}), L$ is the estimated coating thickness $(\mathrm{m}), A$ is the area of gas flow $\left(\mathrm{m}^{2}\right)$, and $\Delta P$ is the pressure drop $(\mathrm{Pa})$. The area, $A$, was fixed using $10.5 \mathrm{~mm}$ diameter orings for sealing and the pressure drop was fixed at 4 points between 0 and $5.2 \mathrm{kPa}(0-0.75 \mathrm{psi})$. The coating thickness was estimated using a cross-sectional backscattered electron (BSE) image taken at low magnification $(\leq 100 \times)$ and an image analysis technique whereby a fixed number of lines (200) in a grid were overlaid across the coating thickness and the average length was measured. The contribution of the $1.6 \mathrm{~mm}$ thick porous substrates to the permeability was removed by measuring the average permeability of 4 of each of the MG0.2 and MG1 substrates. The porosity of the coatings was also estimated using an image analysis technique on BSE images obtained using SEM.

\subsection{Cell Fabrication and Electrochemical Testing}

Anode layers for metal-supported fuel cells were fabricated on MG1 substrates using the nominal plasma spray conditions, as well as $200 \mathrm{~A}$ per cathode, $20 \mathrm{wt} \%$ potato starch in the SDC feedstock, and a plasma gas flow rate of either 150 (Cell C) or 200 slpm (Cell B). Anode coatings processed with a plasma gas flow rate of $200 \mathrm{slpm}$ were also fabricated without the use of a pore former (Cell A) in order to observe the effect on cell performance.

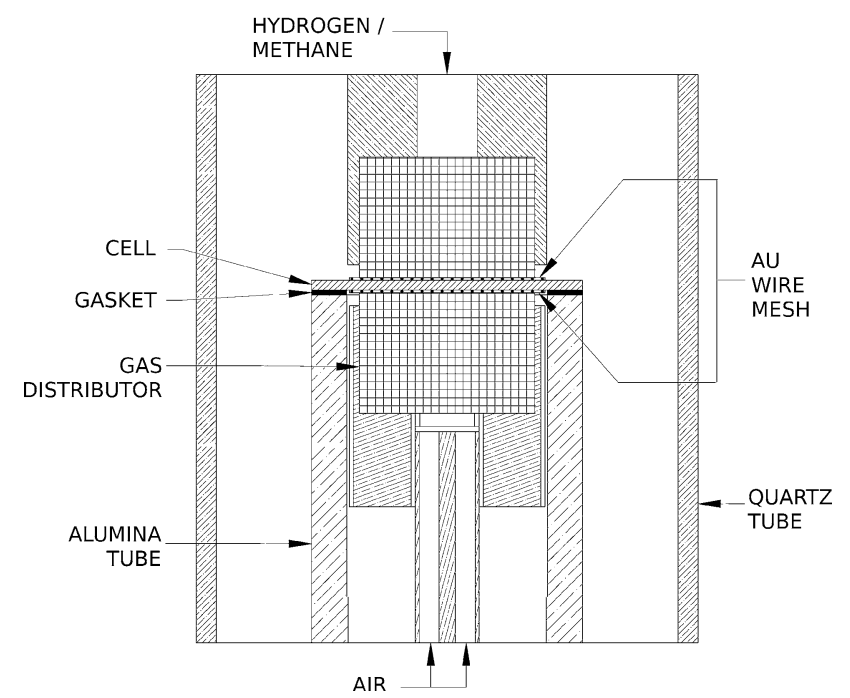

Fig. 2 Basic schematic of the custom cell mounting and sealing assembly used for electrochemical testing of the plasma-sprayed cells
Yttria-stabilized zirconia (YSZ) electrolytes followed by $\mathrm{La}_{0.6} \mathrm{Sr}_{0.4} \mathrm{Co}_{0.2} \mathrm{Fe}_{0.8} \mathrm{O}_{3-\delta}$ (LSCF)-SDC (60/40 wt.\%) cathodes were subsequently plasma sprayed onto the anode layer with the Mettech torch using conditions identified in other studies (Ref 22). Prior to depositing the electrolytes, the anode coatings were reduced in a tube furnace $(40 \%$ $\mathrm{H}_{2}$, balance $\mathrm{N}_{2}$ for $2 \mathrm{~h}$ at $600{ }^{\circ} \mathrm{C}$ ) and lightly sanded with 320 grit SiC paper in order to remove some of the surface roughness. Electrolytes approximately $30 \mu \mathrm{m}$ in thickness were suspension plasma sprayed using a 3 vol. \% aqueous suspension of YSZ (Inframat Advanced Materials) and a rotating turntable for mounting the cells and keeping them cool during spraying. The rotation speed was 250 RPM. Cathodes $1.1 \mathrm{~cm}$ in diameter $\left(\sim 1 \mathrm{~cm}^{2}\right)$ and approximately $50-90 \mu \mathrm{m}$ thick were plasma sprayed onto the electrolytes using a co-spray-dried plasma spray powder (Inframat Advanced Materials) and the same substrate mounting and cooling assembly used for spraying the anode layers.

Cells were tested using a custom-built testing assembly, the basic details of which are provided in Fig. 2. The cells were mounted with the cathode side facing down and sealed against an alumina tube using a vermiculite-based gasket (Thermiculite 866, Flexitallic L.P., Texas, USA). The inside of the alumina tube was exposed to air, while the outside of the tube was exposed to the fuel atmosphere, both at approximately $1 \mathrm{~atm}$ pressure. The fuel gases were humidified by bubbling through water at room temperature. Permeable ceramic gas distributors facilitated equal distribution of the gases over each side of the cell. A quartz tube enclosed the entire assembly to seal the fuel atmosphere. Electrical contacts were made using $\mathrm{Au}$ mesh with wire $0.25 \mathrm{~mm}$ in diameter. $\mathrm{Pt}$ or $\mathrm{Au}$ wool was used on the cathode side in order to insure contact in case of any concave curvature of the cell resulting from the plasma spray process. The rear of the substrate was sanded prior to testing in order to remove any oxide scale that formed during processing. The cells were heated to temperatures of $650-800{ }^{\circ} \mathrm{C}$ in increments of $50{ }^{\circ} \mathrm{C}$ at a rate of

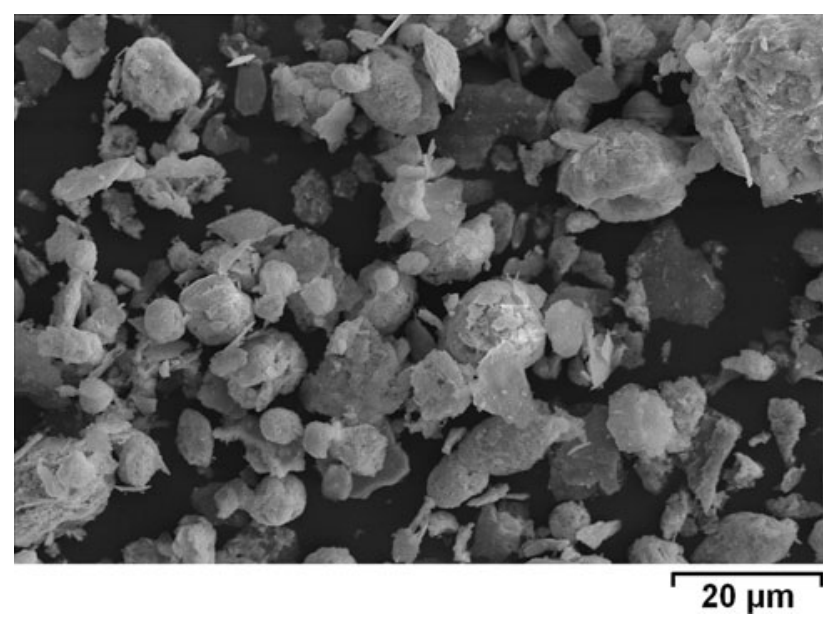

Fig. 3 Secondary electron image of the fine cut spray-dried SDC powder used for plasma spraying

\section{.}


$5{ }^{\circ} \mathrm{C} / \mathrm{min}$. Reduction of the anodes, which became partially oxidized after plasma spraying the electrolyte and cathode layers, was carried out in-situ at a temperature of $600{ }^{\circ} \mathrm{C}$ after heating to this temperature in $4 \% \mathrm{H}_{2}$ (balance $\mathrm{N}_{2}, 200 \mathrm{sccm}$ ). The air flow rate on the cathode side was fixed to $1000 \mathrm{sccm}$. Polarization measurements of the cell were conducted from the open circuit voltage (OCV) to $0.3 \mathrm{~V}$ (Model 1470E CellTest System, Solartron Analytical, Hampshire, UK). Impedance measurements were performed at $\mathrm{OCV}$ in the frequency range of $100 \mathrm{kHz}$ to $0.1 \mathrm{~Hz}$ at a temperature of $750{ }^{\circ} \mathrm{C}$ (Model $1455 / 1451$ FRA, Solartron Analytical) using a perturbation voltage of $20 \mathrm{mV}$. Cell performance was assessed in $\mathrm{H}_{2}$ for all three cells and additionally assessed in $\mathrm{CH}_{4}$ for the cells fabricated with pore former in the feedstock.

\section{Results and Discussion}

\subsection{SDC Powder}

An image of the SDC powder used for plasma spraying in this study is provided in Fig. 3. The powder is made up of dense and rather spherical agglomerates as well as flakes of dense material. Some of the agglomerates can be seen to also contain flakes as primary particles. The density of the agglomerates explains why little breakup was observed after feeding through the powder hopper. Initially, the poor flowability of the flake-like particles in the powder made feeding of the powder difficult. Shortening the powder feed tube and drying the powder for $24 \mathrm{~h}$ alleviated any problems of clogging and intermittent powder flow. While a powder of this type is not ideal for conventional plasma spraying, it was deemed necessary in order to provide a closer match in size to the metal oxide powders fed in

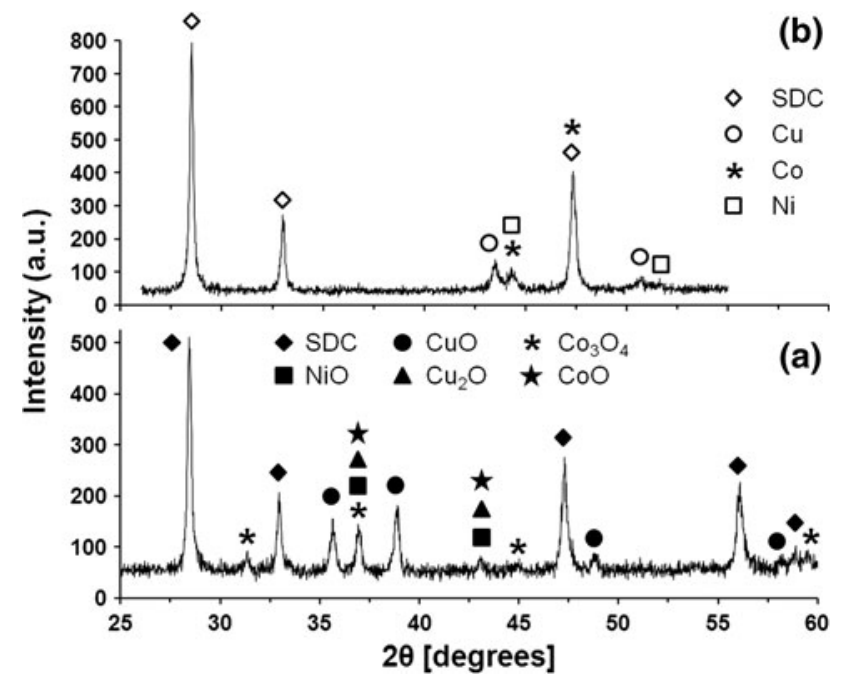

Fig. 4 Typical XRD patterns of composite SOFC anode coatings plasma sprayed with a radial-axial hybrid technique at a standoff distance of $50 \mathrm{~mm}$ either (a) as sprayed or (b) after reduction in hydrogen suspension. It was shown in earlier work that co-spraying metal oxides of the same size in suspension with SDC in dry powder form in a size range of $-45+32 \mu \mathrm{m}$ led to coatings that were less evenly mixed (Ref 23).

\section{$3.2 X R D$}

Typical XRD patterns for coatings fabricated using this technique are shown in Fig. 4. The only phases explicitly identified in the as-sprayed coatings were the cubic phases of $\mathrm{SDC}, \mathrm{CuO}$, and $\mathrm{Co}_{3} \mathrm{O}_{4}$, and no metallic phases were identified. The overlap in the peaks between $\mathrm{NiO}, \mathrm{Cu}_{2} \mathrm{O}$, and $\mathrm{CoO}$ makes it difficult to determine if these phases are present. Also, the peak at approximately $37^{\circ}(2 \theta)$ corresponds to the major peak of the spinel phase of $\mathrm{Co}_{3} \mathrm{O}_{4}$ in the (311) plane, which further masks the presence of $\mathrm{NiO}$, $\mathrm{Cu}_{2} \mathrm{O}$, and $\mathrm{CoO}$, the secondary peaks $(\mathrm{NiO}, \mathrm{CoO})$ and major peak $\left(\mathrm{Cu}_{2} \mathrm{O}\right)$ of which also exist at this angle. $\mathrm{Cu}_{2} \mathrm{O}$ has previously been demonstrated to form during atmospheric plasma spraying by partial reduction of $\mathrm{CuO}$ in flight, forming more preferentially in lower energy plasma conditions (Ref 17,23). Above $900{ }^{\circ} \mathrm{C}, \mathrm{Co}_{3} \mathrm{O}_{4}$ decomposes to $\mathrm{CoO}$. The preservation of the spinel phase of cobalt oxide during plasma spraying may be due to the very short residence time of the material in the plasma, particularly at the short standoff distance of $50 \mathrm{~mm}$. After reduction, the SDC maintained its cubic form. A very minor peak at approximately $52^{\circ}(2 \theta)$ suggests that $\mathrm{Ni}$ is present, although the target amount of $\mathrm{Ni}$ metal in the final coating after reduction was only 4 wt.\%, which would be difficult to detect by XRD. The presence of $\mathrm{Cu}$ is evident, while the presence of Co is likely the reason for the peak at $44.5^{\circ}$ $(2 \theta)$, due to the higher content of $\mathrm{Co}_{3} \mathrm{O}_{4}$ in the suspension feedstock relative to $\mathrm{NiO}$. The hexagonal cobalt phase could not be distinguished from the cubic cobalt phase because of overlap with the secondary SDC peak. Overlap

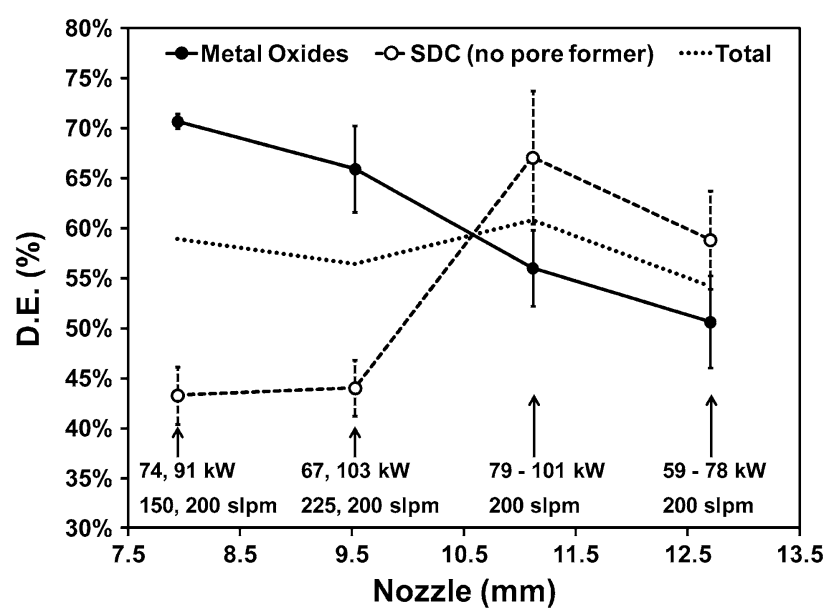

Fig. 5 Total deposition efficiency (DE) and DE of both feedstocks for coatings fabricated at a standoff distance of $50 \mathrm{~mm}$ (range of plasma conditions for each nozzle diameter also shown-error bars correspond to variability in the measurements of one standard deviation) 
among the metal and SDC phase peaks also makes identification of any solid solution phases, such as $\mathrm{Cu}-\mathrm{Ni}$ or Co-Ni, not possible.

\subsection{Deposition Efficiency}

When pore former was not added to the SDC feedstock, the total DE was largely consistent at approximately $58 \%$ at a standoff distance of $50 \mathrm{~mm}$ across a range of nozzle diameters, gas flow rates, and plasma powers, as shown in Fig. 5. The DE of each feedstock was more strongly dependent on the torch nozzle diameter than on plasma power and gas flow rate. For the binary metal oxides, the DE tended to drop with increasing nozzle diameter. There may be two possible reasons for this result. First, increasing the nozzle diameter would result in a decrease in plasma velocity. This decrease in velocity may allow the atomized suspension droplets to spread farther from the plasma center to the cooler fringes of the jet and cause them to go untreated. Second, the resultant lower plasma velocity from the larger nozzle diameter increases the residence time of the particles in the plasma. The higher residence time could cause vaporization of the metal oxide particles, particularly the $\mathrm{CuO}$, which has the lowest melting temperature of the three. Among 28 coatings fabricated using the suspension specified in Table 1 , the average concentrations by weight of $\mathrm{Cu}, \mathrm{Co}$, and $\mathrm{Ni}$ relative to the total metal content were 53.4, 37.6 and $9.0 \%$, respectively, with standard deviations of 1.7 , 1.5 , and $0.5 \%$, respectively. Compared to the target composition of 60,32 , and $8 \%$ for $\mathrm{Cu}, \mathrm{Co}$, and $\mathrm{Ni}$, respectively, it is evident that losses of $\mathrm{Cu}$ during plasma spraying are more prevalent than those of $\mathrm{Co}$ or $\mathrm{Ni}$, suggesting that the use of an aqueous medium for suspending the $\mathrm{CuO}$ has not completely prevented the vaporization of $\mathrm{CuO}$ during spraying. For the SDC, a marked increase in DE was observed after increasing the torch nozzle diameter from $9.5 \mathrm{~mm}$ (0.375 in.) to $11.1 \mathrm{~mm}$ (0.4375 in.). This increase

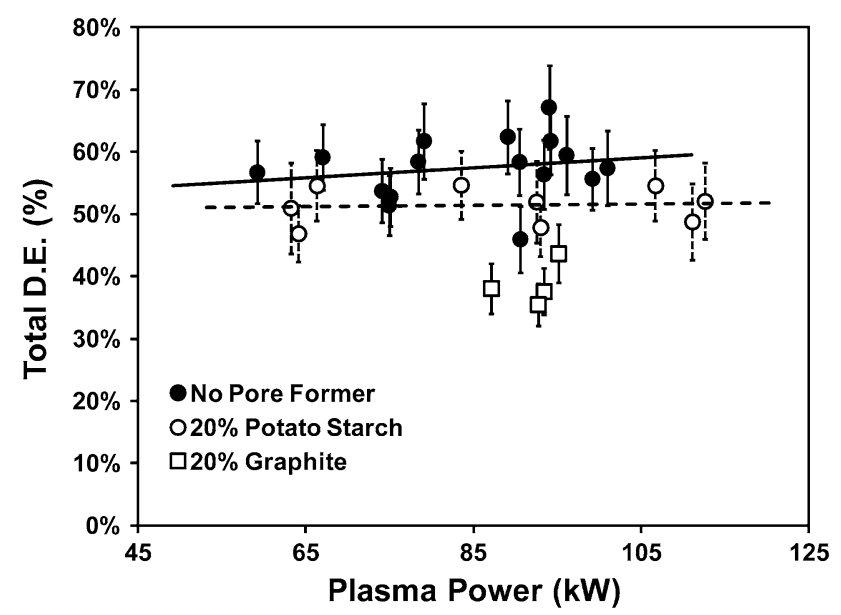

Fig. 6 Effect on total DE of the use of $20 \%$ pore former in the dry powder feedstock for coatings fabricated over a range of plasma powers (errors bars correspond to measurement uncertainty) may be related to better entrainment of the SDC particles, which were radially injected. Lower plasma gas velocities would allow the SDC to advance further into the plasma jet and closer to the hot plasma core, leading to more substantial melting. At a standoff distance of $100 \mathrm{~mm}$ using the nominal plasma spray conditions, total DE dropped by approximately $60 \%$ and the DE of the SDC phase dropped to close to zero. It has been shown previously that the DE of larger SDC particles in similar plasma conditions drops significantly upon increasing the standoff distance from 75 to $100 \mathrm{~mm}$ (Ref 24). In this case, the effect may be more substantial because of the finer average SDC particle size relative to that in the previous study.

The use of a pore former had several effects. First, with the use of potato starch, the average total DE decreased by approximately $5-10 \%$, as shown in Fig. 6. For graphite, the total DE decreased by about $20 \%$. In both cases, the DE of the SDC dropped more significantly than that of the binary metal oxides. For both pore formers, the average DE of the binary metal oxides dropped by less than $10 \%$. However, the average DE of the SDC dropped by $15 \%$ with the potato starch and $35 \%$ with the graphite. The higher decrease associated with the use of graphite is likely related to the fact that it does not melt in the plasma, but tends to sublime. Relatively large, unmelted graphite particles in the coating may inhibit the ability of partially or fully melted SDC particles to adhere to the coating by disrupting the bonding between the successive SDC splats. Potato starch may be less obstructive to the deposition of SDC in the coating because it is partially burned away during the plasma spray process (Ref 25), making it likely that any unmelted potato starch particles reaching the substrate are relatively small compared to the graphite.

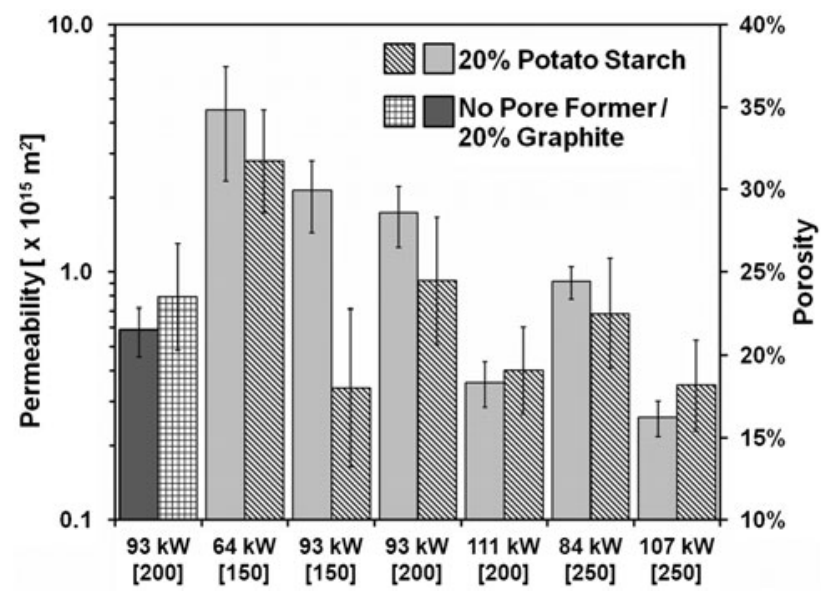

Fig. 7 Permeability (solid bars) and porosity (hatched bars) of coatings fabricated with or without the use of pore former in the SDC feedstock at a range of plasma powers and plasma gas flow rates (shown in brackets) using the nominal plasma spray conditions (errors bars correspond to measurement error due to coating thickness measurement for permeability and uncertainty in the estimations of porosity)

政 

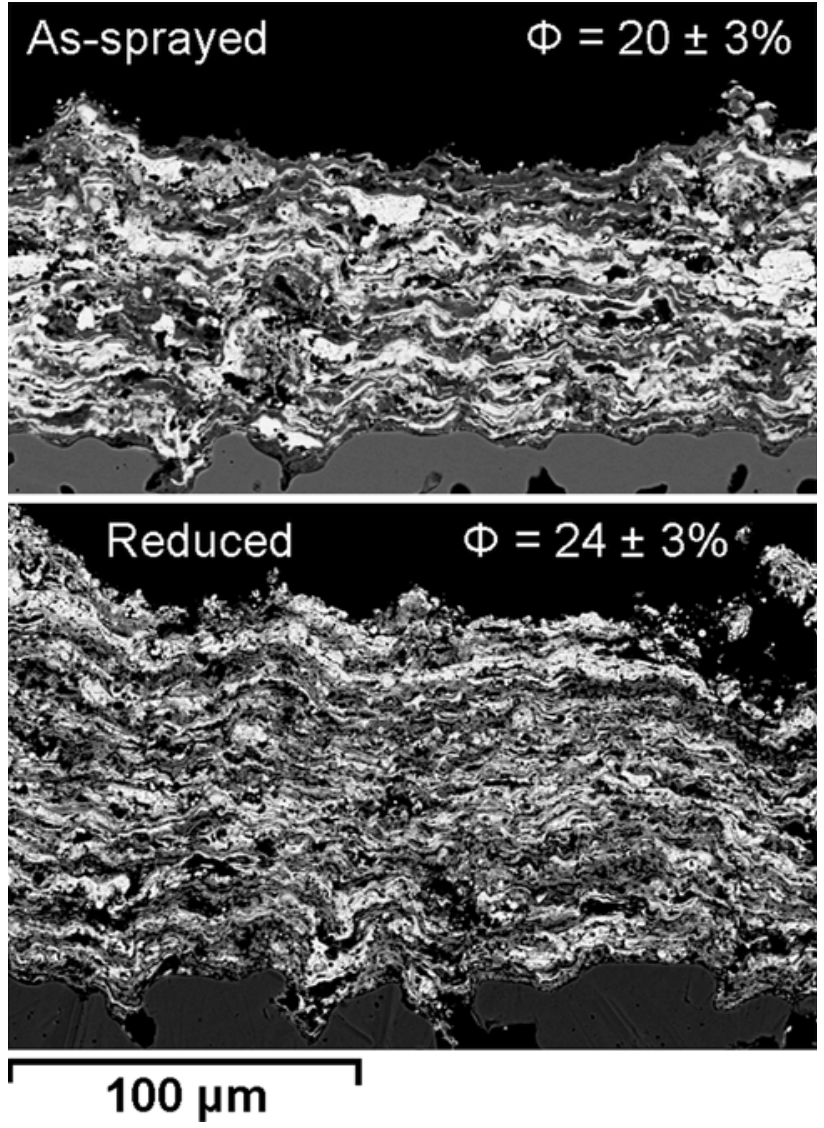

Fig. 8 Backscattered electron (BSE) images before and after reduction of two different composite coatings containing $\mathrm{Cu}, \mathrm{Co}$, $\mathrm{Ni}$, and SDC, fabricated without pore former and using the nominal plasma spray conditions, 200 A per cathode $(93 \mathrm{~kW})$ and a plasma gas flow rate of $200 \mathrm{slpm}$ (estimated porosity also shown)

\subsection{Porosity and Permeability}

The measured permeability and estimated porosity for coatings fabricated with and without both pore formers using the nominal plasma spray conditions are provided in Fig. 7. The addition of graphite to the SDC feedstock demonstrated no significant effect on the permeability or porosity of the resultant coatings, suggesting that little graphite ended up in the coatings. The addition of potato starch increased coating permeability for a plasma power of $93 \mathrm{~kW}$ and a plasma gas flow rate of $200 \mathrm{slpm}$. However, the increase in the estimated porosity with pore former for the same processing conditions was marginal and within the margins of error. Low plasma powers and low plasma gas flow rates led to the highest levels of porosity and permeability. Generally, both porosity and permeability were found to be inversely related to both plasma gas flow rate and plasma power. Porosity on the order of 40 vol.\% (Ref 16) and permeability coefficients on the order of $10^{-14} \mathrm{~m}^{2}$ (Ref 26) have been found to be suitable for gas transport in an SOFC anode, suggesting that additional means are necessary to further improve the porosity and permeability of SOFC anode coatings
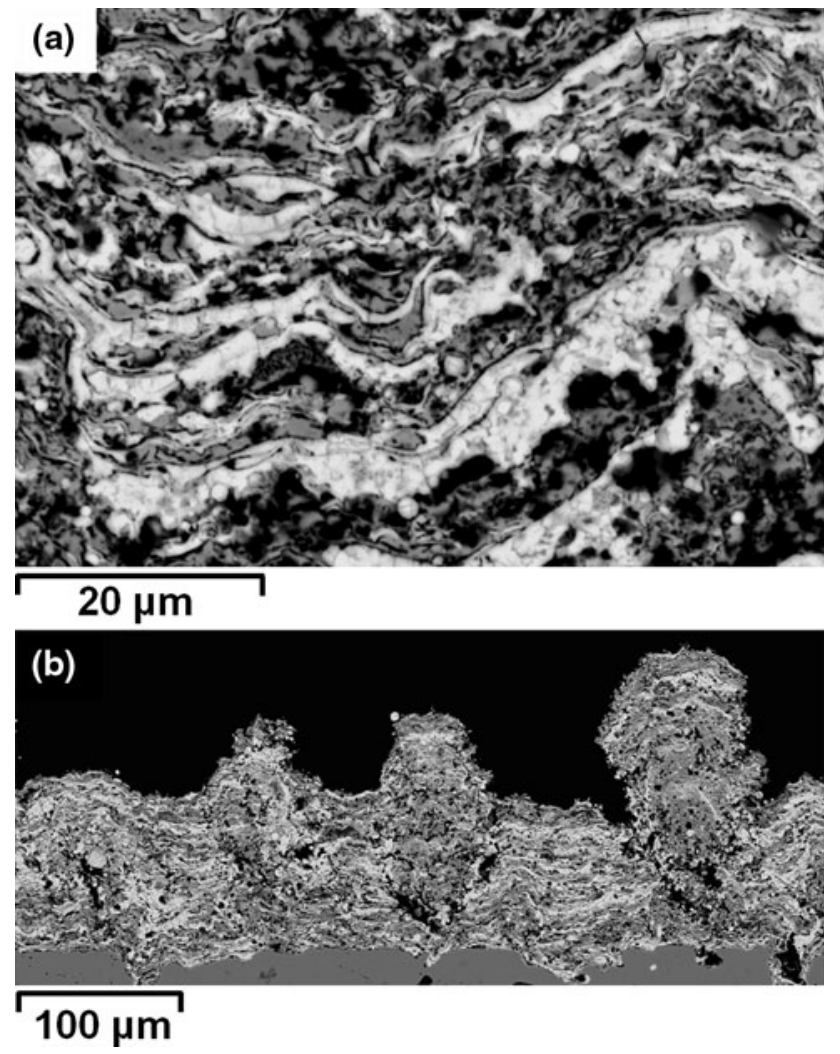

Fig. 9 Typical BSE images of coatings fabricated with pore former after reduction in hydrogen at (a) high magnification and (b) low magnification

fabricated with this hybrid process. This increase may be accomplished through the additional inclusion of a pore former in the aqueous suspension.

\subsection{SEM}

The microstructures of coatings fabricated without pore former using the nominal plasma spray conditions before and after reduction in hydrogen are shown in Fig. 8. While in some areas the coatings appear to be well mixed, other portions of the coating appear layered between the brighter SDC regions and the darker metal regions. Fine networks of porosity associated with the reduction of the metals increased the porosity of these coatings by an estimated $4 \%$. Layering may be a result of the density difference of the two feedstocks or differences in the trajectory of particle flow in the radial direction in the plasma. The well-mixed areas may be a result of a localized disturbance affecting the deposition of either feedstock, such as an underlying surface feature leading to localized surface roughness. Adjustment of the SDC carrier gas flow rate and radial injector diameter to allow better alignment of the two particle streams in the plasma may help to alleviate this effect. In all of the plasma spray conditions investigated, adhesion of the coatings to the substrates was high, based on observations and simple scratch tests.

Images showing the typical microstructure and surface roughness character of coatings fabricated with pore 
former at high and low magnification are provided in Fig. 9. At higher magnification, some regions in the coatings show fine levels of mixing between the two phases. Unmelted or resolidified spherical particles of SDC are also present, either alone or within the splat structures. Porosity is made up of regions between the lamellae and connected networks of globular pores. Some of the large $(\sim 5 \mu \mathrm{m})$ pores may be due to potato starch particles embedded in the coating before being burned away or due to pullout of spherical particles during sample preparation. The typical character of the surface roughness, as shown in Fig. 9(b), appears to be made up of both columnar-type and "bump"-type features. Coatings

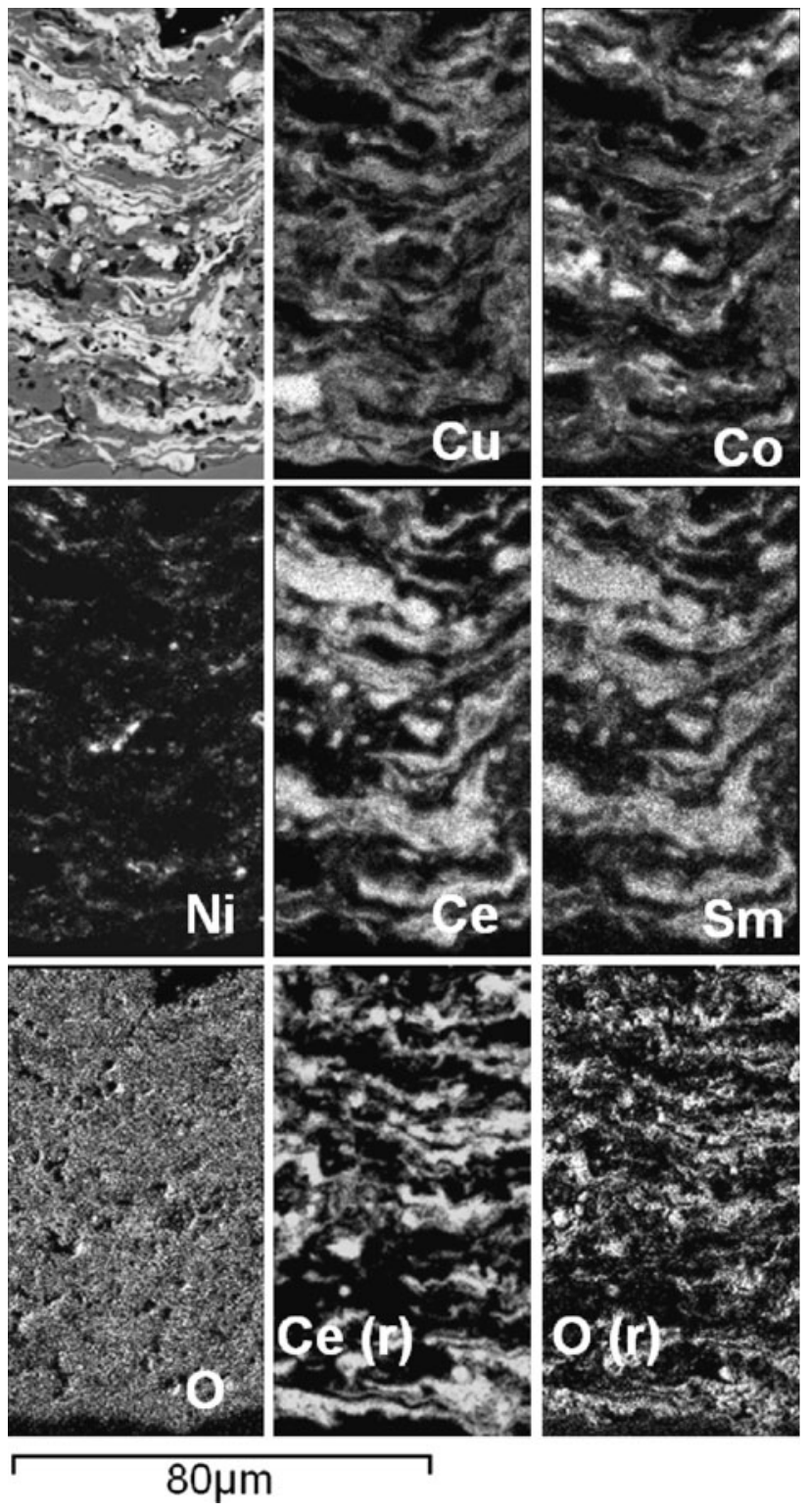

Fig. 10 Elemental maps of $\mathrm{Cu}, \mathrm{Co}, \mathrm{Ni}, \mathrm{Ce}, \mathrm{Sm}$, and $\mathrm{O}$ of an assprayed coating obtained using EDX, showing the BSE image at top left-maps of $\mathrm{Ce}$ and $\mathrm{O}$ for a similar coating after reduction in a tube furnace are also shown labeled $\mathrm{Ce}(\mathrm{r})$ and $\mathrm{O}(\mathrm{r})$, respectively fabricated using nozzle diameters of $11.1 \mathrm{~mm}$ or higher led to higher amounts of surface roughness.

Coating roughness in suspension plasma spraying has been attributed to a number of factors. Some studies have suggested that the plasma gas boundary layer formed at the substrate surface during spraying can deflect submicron particles in the direction of the gas flow, causing the particles to deposit on asperities in the coating and form columnar-type structures (Ref 20). Others have attributed similar types of roughness to arc root fluctuations in the plasma jet, particularly for plasmas containing diatomic gases, leading to more random trajectories of the particles in the plasma and more random degrees of particle melting (Ref 19, 27). Particle vaporization has also been suggested (Ref 19). Based on previous results, the vaporization of SDC during atmospheric plasma spray processes seems likely (Ref 20,24) and may be leading to some of the observed coating roughness. The short standoff distance used, which would lead to thicker boundary layers at the substrate, and the use of both $\mathrm{H}_{2}$ and $\mathrm{N}_{2}$ in the plasma, which would contribute to plasma fluctuation, may also be contributing to the observed coating roughness in this study, although the three electrode pairs used in the torch tend to minimize arc root fluctuations. Coating roughness in conventional thermal spraying of dry powders has been attributed to the splashing of molten droplets, in both plasma-sprayed alumina (Ref 28) and $\mathrm{CrC}-\mathrm{NiCr}$ sprayed with a high velocity oxygen fuel (HVOF) process (Ref 29), resulting in localized regions of porosity that initiate the growth of coating "bumps." The high particle velocities associated with the short standoff distance used in this study make this hypothesized effect another possible contributing factor to the resultant surface roughness.

An elemental map showing regions of $\mathrm{O}, \mathrm{Cu}, \mathrm{Co}, \mathrm{Ni}, \mathrm{Ce}$, and Sm obtained using EDX on an as-sprayed coating is provided in Fig. 10. Oxygen appears relatively equally distributed throughout the bulk of the coating, except for the pore regions. This result agrees with the XRD pattern obtained for the as-sprayed coating, which did not indicate the presence of any purely metallic phases. As expected, $\mathrm{Cu}$ and Co appear abundant throughout the coating, while the $\mathrm{Ni}$, which is only present in amounts of approximately $4 \mathrm{wt} . \%$, appears scattered throughout the coating in small concentrated deposits $(\sim 1-10 \mu \mathrm{m})$. The sizes of the deposits are on the order of the measured particle sizes of the bulk $\mathrm{NiO}$ powder (Table 1). Also shown in Fig. 10 are the $\mathrm{Ce}$ and $\mathrm{O}$ maps for a similar coating after reduction with $\mathrm{H}_{2}$ in a tube furnace $\left(40 \% \mathrm{H}_{2}\right.$, balance $\left.\mathrm{N}_{2}\right)$ for $2 \mathrm{~h}$ at $600{ }^{\circ} \mathrm{C}$. After reduction, the locations of $\mathrm{O}$ match closely to the locations of $\mathrm{Ce}$, suggesting that a majority of the binary metallic oxides were completely reduced to their metallic form along the entire width of the coating.

The effects of plasma gas flow rate on the resulting microstructures of coatings fabricated using the nominal plasma spray conditions and potato starch as a pore former are illustrated in Fig. 11. The average coating composition did not change as the plasma gas flow rate increased, in contrast to the observations for decreases in nozzle diameter presented earlier (Fig. 5), which showed an increase in the relative metal content in the coating due 

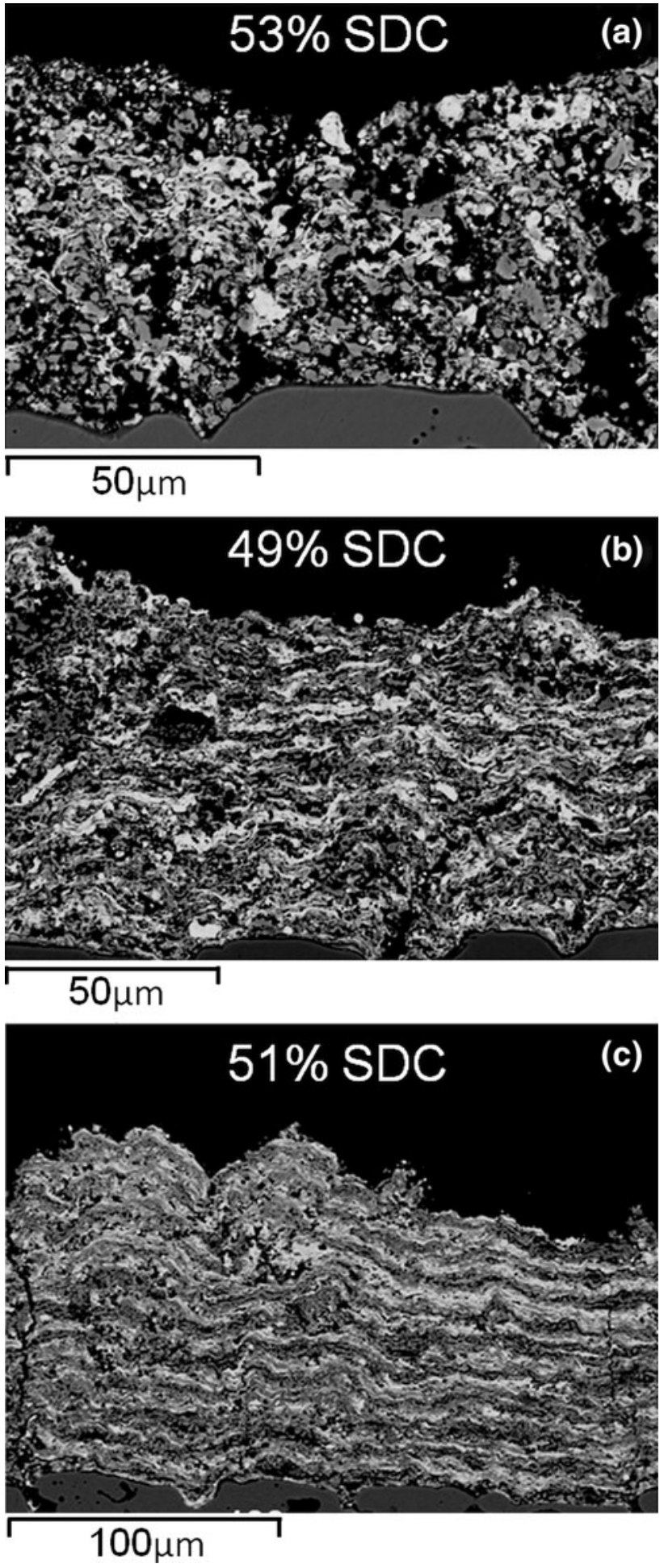

Fig. 11 BSE images of coatings fabricated using the nominal plasma spray conditions with $20 \%$ potato starch in the SDC feedstock after reduction in hydrogen, using 200 A per cathode, $50 \mathrm{~mm}$ standoff distance, and a plasma gas flow rate of (a) $150 \mathrm{slpm}$, (b) $200 \mathrm{slpm}$, and (c) $250 \mathrm{slpm}$ (vol.\% SDC is also shown)

to a drastic reduction in the $\mathrm{DE}$ of SDC with smaller nozzle diameters. Layering between the SDC and the metals in the coatings increases with plasma gas flow rate. The decrease in coating porosity with the increasing gas flow rate demonstrated in Fig. 7 can be seen visually in Fig. 11. The numerous large pore areas contributing to the high porosity at lower gas flow rates disappear as the gas flow rate is increased. The high porosity at lower gas flow rates may be associated with higher amounts of pore former depositing in the coating. The presence of fewer splatlike structures suggests that it may also be associated with lower levels of melting of the particles in flight, leading to partially melted particles that prevent the ordered deposition of splats and contribute to the formation of voids. The implications of the microstructures presented in Fig. 11 on the performance of these coatings as anodes of an SOFC are twofold. First, the higher levels of porosity in coatings fabricated with low gas flow rates would be more beneficial to anode performance, allowing higher rates of gas exchange at the active sites within the electrode. Second, the layering of the SDC and the metals at higher gas flow rates would be detrimental to anode performance. The flow of electrons to the metal substrate acting as a current collector and the flow of oxygen ions to the electrolyte from the active sites would face more resistance as the charge carriers would be forced to flow parallel to the substrate. The better mixing and higher porosity in the coatings fabricated at low gas flow rates make them more suitable for use as an SOFC electrode.

\subsection{Fuel Cell Testing}

The suspension formulation was adjusted to account for the loss in $\mathrm{Cu}$ during processing to $66.4 \% \mathrm{CuO}, 27.2 \%$ $\mathrm{Co}_{3} \mathrm{O}_{4}$, and $6.4 \% \mathrm{NiO}$ (wt.\%/solids). The resulting metal concentrations in the coatings fabricated for fuel cell testing were closer to the targeted value of $30 \mathrm{wt} . \% \mathrm{Cu}$, 16 wt. \% Co, and 4 wt. \% Ni (assuming 50/50 wt.\% metals:SDC), as shown in Table 3. Cell A was fabricated using the original suspension formulation, while cells B and C were fabricated using the modified formulation. The decrease in the DE of the SDC with the addition of pore former is also apparent as the concentration of the SDC in the coatings decreased after the addition of potato starch.

The results of electrochemical testing in $\mathrm{H}_{2}$ for cells $\mathrm{A}$, $\mathrm{B}$, and $\mathrm{C}$ are also provided in Table 3 . Overall, the anodes fabricated using this technique demonstrated good electrochemical performance. These results may be related to the use of the finely sized metal oxide powders in suspension as well as the high levels of mixing present in regions of the coatings. Combustion of the fuel caused by gas crossover across the electrolyte and/or cell seal strongly limited the performance of all three cells. For example, the voltage at $700{ }^{\circ} \mathrm{C}$ in bubble-humidified $\mathrm{H}_{2}$ for all three cells ranged from 132 to $178 \mathrm{mV}$ lower than the Nernst potential $(1.119 \mathrm{~V})$. Using the average measured $\mathrm{OCV}$ at $700{ }^{\circ} \mathrm{C}$, and assuming that the majority of combustion occurred on the anode side, the expected 
Table 3 Details of the fabrication, composition, and performance of metal-supported cells containing anodes fabricated using nominal plasma spray conditions and 200 A per cathode

\begin{tabular}{|c|c|c|c|c|c|c|c|c|c|c|}
\hline \multirow[b]{2}{*}{ Cell } & \multirow{2}{*}{$\begin{array}{c}\text { Plasma gas flow } \\
\text { rate, slpm }\end{array}$} & \multirow[b]{2}{*}{ Pore former ${ }^{b}$} & \multicolumn{4}{|c|}{ Anode composition } & \multicolumn{4}{|c|}{ Power density at $0.7 \mathrm{~V}, \mathrm{~mW} / \mathrm{cm}^{2}$ a $(\mathrm{OCV})$} \\
\hline & & & wt. \% Cu & wt. \% Co & wt. \% Ni & wt. \% SDC & $650^{\circ} \mathrm{C}$ & $700^{\circ} \mathrm{C}$ & $750^{\circ} \mathrm{C}$ & $800^{\circ} \mathrm{C}$ \\
\hline A & 200 & None & 22.4 & 17.4 & 4.6 & 55.6 & $90(0.962)$ & $136(0.942)$ & $171(0.914)$ & $258(0.915)$ \\
\hline $\mathrm{B}$ & 200 & 20 wt. $\%$ PS & 31.0 & 16.8 & 4.1 & 48.1 & $96(1.004)$ & $167(0.988)$ & $215(0.972)$ & $320(0.962)$ \\
\hline $\mathrm{C}$ & 150 & 20 wt. $\%$ PS & 33.7 & 15.8 & 3.8 & 46.7 & $139(0.981)$ & $228(0.953)$ & $314(0.923)$ & $366(0.885)$ \\
\hline
\end{tabular}

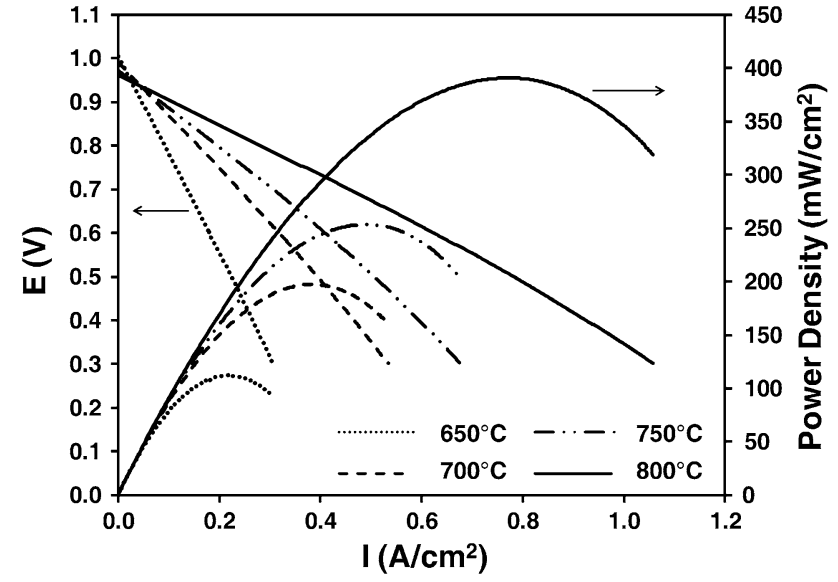

Fig. 12 Electrochemical performance of cell B-anode 200 sccm $\left(97 \% \mathrm{H}_{2}-3 \% \mathrm{H}_{2} \mathrm{O}\right)$, cathode $1000 \mathrm{sccm}$ (air)

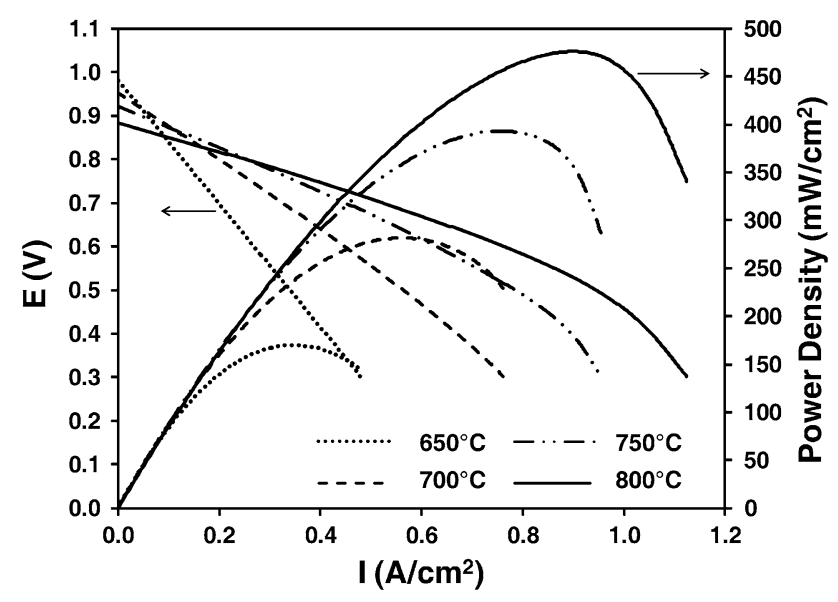

Fig. 13 Electrochemical performance of cell C-anode $200 \mathrm{sccm}\left(97 \% \mathrm{H}_{2}-3 \% \mathrm{H}_{2} \mathrm{O}\right)$, cathode $1000 \mathrm{sccm}$ (air)

gas composition at the anode would have been approximately $40 / 60 \% \mathrm{H}_{2} / \mathrm{H}_{2} \mathrm{O}$. The combustion of $\mathrm{H}_{2}$ on only the anode side is not an unlikely assumption as the pressure at the cathode side was slightly larger than that at the anode side by approximately $5 \mathrm{kPa}(0.73 \mathrm{psi})$ due to the higher flow rate of air. Nonetheless, power densities at $0.7 \mathrm{~V}$ as high as $366 \mathrm{~mW} / \mathrm{cm}^{2}\left(475 \mathrm{~mW} / \mathrm{cm}^{2}\right.$ peak $)$ at

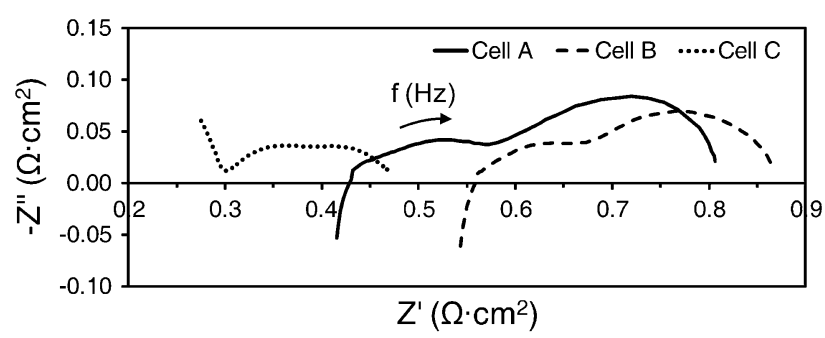

Fig. 14 Nyquist plot of the impedance of cells A, B, and C at $750{ }^{\circ} \mathrm{C}$

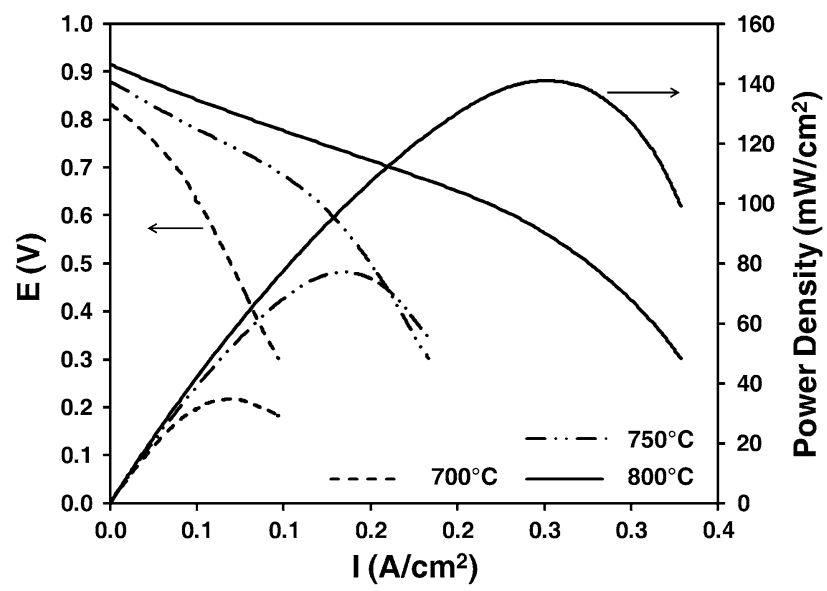

Fig. 15 Electrochemical performance of cell B-anode 2.2 slpm $\left(97 \% \mathrm{CH}_{4}-3 \% \mathrm{H}_{2} \mathrm{O}\right)$, cathode 1.0 slpm (air)

$800{ }^{\circ} \mathrm{C}$ for cell $\mathrm{C}$, which had an OCV of $0.89 \mathrm{~V}$, were measured. Aside from reducing the $\mathrm{OCV}$, the combustion of $\mathrm{H}_{2}$ may have reduced the cell performance by increasing the concentration polarization at high current densities. The results of polarization measurements on cells B and C are provided in Fig. 12 and 13, respectively. The increasing slope of the polarization curves at high current densities for cell $\mathrm{C}$ at 750 and $800{ }^{\circ} \mathrm{C}$ may have been due to low $\mathrm{H}_{2}$ partial pressures as a result of both electrochemical oxidation and combustion. The measured OCV values for cell $\mathrm{B}$ were higher than those for cell $\mathrm{C}$, which may be the reason why the polarization curves for cell B maintained a more constant slope at high current densities. 
Based on the power density data alone, it appears that the addition of pore former to the SDC feedstock, as well as a decrease in the plasma gas flow rate, contributed to higher cell performances. Based on the estimates of permeability and porosity for these coatings, which both increased with pore former and a decrease in plasma gas flow rate, higher performance could be attributed to a reduction in mass transfer limitations in the anode. In impedance spectroscopy measurements, this reduction would be apparent as a reduction in the size of the low frequency arc in a Nyquist plot of the imaginary component $\left(Z^{\prime \prime}\right)$ versus the real component $\left(Z^{\prime}\right)$ of the impedance. The results of impedance testing at $750{ }^{\circ} \mathrm{C}$, shown in Fig. 14 , suggest that anode permeability may not have been the only contributing factor. All three cells had distinctly different series resistance $\left(R_{\mathrm{s}}\right)$ values, with cell C having the lowest $R_{\mathrm{S}}$ value $(\sim 0.3 \Omega /$ $\left.\mathrm{cm}^{2}\right)$ and cell B have the largest $R_{\mathrm{s}}$ value $\left(0.56 \Omega / \mathrm{cm}^{2}\right)$. The lack of a high frequency intercept for cell $\mathrm{C}$ was due to inductance contributions at high frequencies, which was the result of using a longer measurement cable and a different frequency response analyzer (FRA) after the original FRA failed during testing of cell C. The lower $R_{\mathrm{s}}$ value of cell C relative to cells A and B may be explained by the higher levels of mixing of the SDC and the metal phases as a result of the lower plasma gas flow rate (Fig. 11). The lower $R_{\mathrm{S}}$ value of cell A relative to cell $\mathrm{B}$, both of which were fabricated using the same gas flow rate, was unexpected and is yet to be explained, but may be related to the lower porosity of the anode in cell $\mathrm{A}$ and corresponding higher electrical conductivity. The low frequency arc for cell $\mathrm{B}$ is smaller than that for cell $\mathrm{A}$, which agrees with the expectation of better mass transfer properties for anodes fabricated with the use of pore former. However, the thickness of the cathode for cell A $(\sim 90 \mu \mathrm{m})$ was larger than that for cells B and C $(\sim 50 \mu \mathrm{m})$ and may be contributing to mass transfer losses as well. As a result, the decrease in cell polarization resistance $\left(R_{\mathrm{p}}\right)$ between cells A and B cannot be solely attributed to the anode permeability. However, the size of the low frequency arc of cell C relative to its higher frequency arc is smaller than that of cell $\mathrm{B}$, suggesting that a reduction in plasma gas flow rates provided even further increases in anode permeability and contributed to higher overall cell performance, as expected.

High levels of combustion at the cell and very low OCVs made testing cell $\mathrm{C}$ in methane impossible, probably due to high levels of steam as a result of combustion. Per mole, the combustion of methane leads to twice as much steam compared to the combustion of hydrogen. The lower levels of combustion in cell $\mathrm{B}$, as demonstrated by the higher OCV values in $\mathrm{H}_{2}$, allowed the cell to be tested in $\mathrm{CH}_{4}$, the results of which are provided in Fig. 15 . A power density of $113 \mathrm{~mW} / \mathrm{cm}^{2}$ at $0.7 \mathrm{~V}\left(140 \mathrm{~mW} / \mathrm{cm}^{2}\right.$ peak) was obtained at $800{ }^{\circ} \mathrm{C}$. The increase in slope at higher current densities suggests severe mass transfer limitations in the cell, possibly related to combustion.

\section{Conclusions}

Composite coatings containing $\mathrm{Cu}, \mathrm{Co}, \mathrm{Ni}$, and SDC have been successfully fabricated using a novel hybrid atmospheric plasma spraying technique, in which a multicomponent aqueous suspension of $\mathrm{CuO}, \mathrm{Co}_{3} \mathrm{O}_{4}$, and $\mathrm{NiO}$ was injected axially simultaneously with SDC injected radially in dry powder form. With this technique, the DE of both the metal oxides and the SDC is more dependent on nozzle diameter than on plasma power or plasma gas flow rate for the conditions defined in this study. Excess $\mathrm{CuO}$ relative to $\mathrm{Co}_{3} \mathrm{O}_{4}$ or $\mathrm{NiO}$ in the suspension is required to compensate for losses during the plasma spray process. Also, pore formers are required to increase coating porosity to levels more suitable for an SOFC anode. Several modes of defect formation likely contribute to significant surface roughness in the coatings, which must be overcome before use of this process for rapid SOFC fabrication is possible. Depending on the processing conditions, the SDC and the metal phases can be either very well mixed or layered. The potential for a high level of mixing between the co-sprayed phases makes this hybrid technique a promising option for plasma spraying composite SOFC electrodes as demonstrated by the good performance of plasma-sprayed cells in both $\mathrm{H}_{2}$ and $\mathrm{CH}_{4}$ in non-ideal testing conditions.

\section{Acknowledgments}

The authors gratefully acknowledge the financial support of the Natural Science and Engineering Research Council of Canada (NSERC) as well as the assistance of Mr. Jeff Harris and Mr. Michael Marr in providing conditions for the plasma spray processing of the cathodes and the electrolytes for the cells. Donation of gasket materials by Flexitallic is also gratefully acknowledged.

\section{References}

1. J.R. Rostrup-Nielsen, Conversion of Hydrocarbons and Alcohols for Fuel Cells, Phys. Chem. Chem. Phys., 2001, 3, p 283-288

2. H. Kim, C. Lu, W.L. Worrell, J.M. Vohs, and R.J. Gorte, Cu-Ni Cermet Anodes for Direct Oxidation of Methane in Solid-Oxide Fuel Cells, J. Electrochem. Soc., 2002, 149, p A247-A250

3. N.Q. Minh, Ceramic Fuel-Cells, J. Am. Ceram. Soc., 1993, 76, p 563-588

4. L. Jiang, B.D. Madsen, J. Zhiqiang, and S.A. Barnett, A FuelFlexible Ceramic-Based Anode for Solid Oxide Fuel Cells, Electrochem. Solid-State Lett., 2002, 5, p A122-A124

5. S. Lee, K. Ahn, J.M. Vohs, and R.J. Gorte, Cu-Co Bimetallic Anodes for Direct Utilization of Methane in SOFCs, Electrochem. Solid-State Lett., 2005, 8, p A48-A51

6. I. Wolf and H.J. Grabke, A Study on the Solubility and Distribution of Carbon in Oxides, Solid State Commun., 1985, 54, p 5-10

7. D.L. Trimm, The Formation and Removal of Coke from Nickel Catalyst, Catal. Rev. Sci. Eng., 1977, 16, p 155-189

8. H. Yahiro, Y. Eguchi, K. Eguchi, and H. Arai, Oxygen Ion Conductivity of the Ceria-Samarium Oxide System with Fluorite Structure, J. Appl. Electrochem., 1988, 18, p 527-531

9. E.S. Putna, J. Stubenrauch, J.M. Vohs, and R.J. Gerte, CeriaBased Anodes for the Direct Oxidation of Methane in Solid Oxide Fuel Cells, Langmuir, 1995, 11, p 4832-4837

10. D.B. Ingram and S. Linic, First-Principles Analysis of the Activity of Transition and Noble Metals in the Direct Utilization of Hydrocarbon Fuels at Solid Oxide Fuel Cell Operating Conditions, J. Electrochem. Soc., 2009, 156, p B1457-B1465 
11. N.M. Galea, D. Knapp, and T. Ziegler, Density Functional Theory Studies of Methane Dissociation on Anode Catalysts in Solid-Oxide Fuel Cells: Suggestions for Coke Reduction, J. Catal., 2007, 247, p 20-33

12. S. Park, J.M. Vohs, and R.J. Gorte, Direct Oxidation of Hydrocarbons in a Solid-Oxide Fuel Cell, Nature, 2000, 404, p 265-267

13. H. Kim, S. Park, J.M. Vohs, and R.J. Gorte, Direct Oxidation of Liquid Fuels in a Solid Oxide Fuel Cell, J. Electrochem. Soc., 2001, 148, p 693-695

14. M.D. Gross, J.M. Vohs, and R.J. Gorte, A Study of Thermal Stability and Methane Tolerance of Cu-Based SOFC Anodes with Electrodeposited Co, Electrochim. Acta, 2007, 52, p 19511957

15. T. Nishizawa and K. Ishida, The Co-Cu (Cobalt-Copper) System, Bull. Alloy Phase Diagr., 1984, 5, p 161-165

16. R. Hui, Z.W. Wang, O. Kesler, L. Rose, J. Jankovic, S. Yick, R. Maric, and D. Ghosh, Thermal Plasma Spraying for SOFCs: Applications, Potential Advantages, and Challenges, J. Power Sources, 2007, 170, p 308-323

17. N. Benoved and O. Kesler, Air Plasma Spray Processing and Electrochemical Characterization of $\mathrm{Cu}-\mathrm{SDC}$ Coatings for use in Solid Oxide Fuel Cell Anodes, J. Power Sources, 2009, 193, p 454461

18. A. Benyoucef, D. Klein, C. Coddet, and B. Benyoucef, Development and Characterisation of $(\mathrm{Ni}, \mathrm{Cu}, \mathrm{Co})-\mathrm{YSZ}$ and $\mathrm{Cu}-\mathrm{Co}-$ YSZ Cermets Anode Materials for SOFC Application, Surf. Coat. Technol., 2008, 202, p 2202-2207

19. P. Fauchais, R. Etchart-Salas, C. Delbos, M. Tognonvi, V. Rat, J.F. Coudert, and T. Chartier, Suspension and Solution Plasma Spraying of Finely Structured Layers: Potential Application to SOFCs, J. Phys. D, 2007, 40, p 2394-2406

20. J. Oberste Berghaus, J.-G. Legoux, C. Moreau, R. Hui, and D. Ghosh, Suspension Plasma Spraying of Intermediate Tempera- ture SOFC Components Using an Axial Injection DC Torch, Mater. Sci. Forum, 2007, 539-543, p 1332-1337

21. M. Cuglietta, K.L. Chaudhary, S. Ge, and O. Kesler, Development of a Multi-Component Aqueous $\mathrm{NiO}, \mathrm{CuO}$, and $\mathrm{Co}_{3} \mathrm{O}_{4}$ Suspension for Use in Suspension Plasma Spraying of SOFC Anode Layers, Powder Technol., 2013, 237, p 76-86

22. J. Harris, M. Qureshi, and O. Kesler, Deposition of Composite LSCF-SDC and SSC-SDC Cathodes by Axial-Injection Plasma Spraying, J. Therm. Spray Technol., 2012, 21, p 461-468

23. M. Cuglietta and O. Kesler, Fabrication of Direct Oxidation Solid Oxide Fuel Cell Anodes Using a Novel Atmospheric Plasma Spraying Technique, ECS Trans., 2011, 35, p 1781-1790

24. M. Cuglietta and O. Kesler, Relationship Between Particle and Plasma Properties and Coating Characteristics of SamariaDoped Ceria Prepared by Atmospheric Plasma Spraying for Use in Solid Oxide Fuel Cells, J. Therm. Spray Technol., 2012, 21, p 448-460

25. M. Poon and O. Kesler, The Influence of Pore Formers on the Microstructure of Plasma-Sprayed NiO-YSZ Anodes, J. Power Sources, 2012, 210, p 204-217

26. H. Weckmann, A. Syed, Z. Ilhan, and J. Arnold, Development of Porous Anode Layers for the Solid Oxide Fuel Cell by Plasma Spraying, J. Therm. Spray Technol., 2006, 15, p 604-609

27. P. Michaux, G. Montavon, A. Grimaud, A. Denoirjean, and P. Fauchais, Elaboration of Porous NiO/8YSZ Layers by Several SPS and SPPS Routes, J. Therm. Spray Technol., 2010, 19, p 317-327

28. R.W. Trice and K.T. Faber, Role of Lamellae Morphology on the Microstructural Development and Mechanical Properties of Small-Particle Plasma-Sprayed Alumina, J. Am. Ceram. Soc., 2000, 83, p 889-896

29. O. Racek, The Effect of HVOF Particle-Substrate Interactions on Local Variations in the Coating Microstructure and the Corrosion Resistance, J. Therm. Spray Technol., 2010, 19, p 841-851 